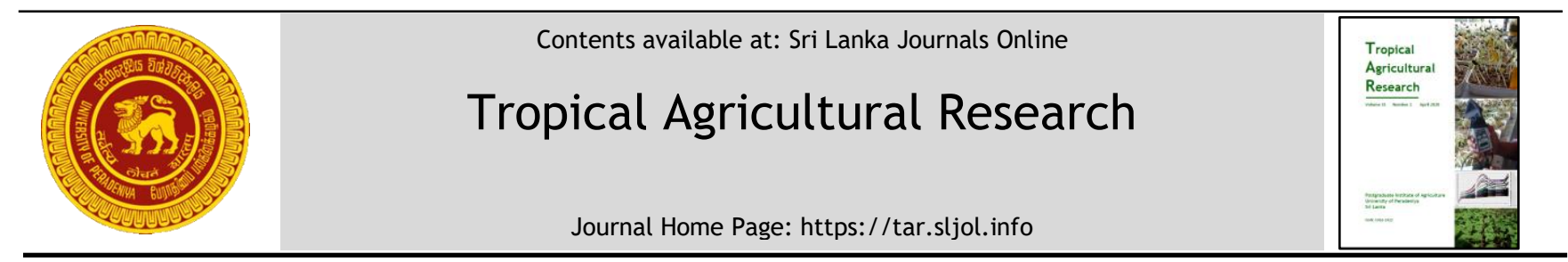

\title{
Field Performance of Mixtures of Pseudomonas and Bacillus spp. in Managing Papaya Ringspot Virus Disease and their Effect on Plant Defense Enzyme Activity
}

\author{
C. Ranasinghe ${ }^{1}$ and D.M. De Costa ${ }^{1,2^{*}}$ \\ ${ }^{1}$ Board of Study-Plant Protection, Postgraduate Institute of Agriculture, University of Peradeniya, Peradeniya, Sri Lanka \\ ${ }^{2}$ Department of Agricultural Biology, Faculty of Agriculture, University of Peradeniya, Peradeniya, Sri Lanka
}

ARTICLE INFO

\section{Article history:}

Received: 29 October 2019

Accepted: 08 November 2019

Available online: 1 April 2020

\section{Keywords:}

Percentage disease index

Peroxidase

Phenylalanine ammonia lyase

$\beta$-1,3-glucanase

\section{Citation: \\ Ranasinghe, C. and De Costa, D.M. (2020). \\ Field Performance of Mixtures of \\ Pseudomonas and Bacillus spp. in \\ Managing Papaya Ringspot Virus Disease and their Effect on Plant Defense Enzyme Activity. Tropical Agricultural Research, 31(2): 75-86.}

DOI: http://doi.org/10.4038/tar.v31i2.8369

Ranasinghe, C.

https://orcid.org/0000-0003-4884-9946

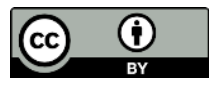

\section{ABSTRACT}

The present study was conducted to determine the field efficacy of Pseudomonas and Bacillus spp., isolated from the rhizosphere of healthy papaya to manage papaya ringspot virus disease (PRSVD), when applied as isolate-mixtures along with their effect on plant defense enzyme activity. Mixtures of bacterial isolates were applied by two methods, namely seed soak (SS) and soil drench (SD) to field-grown and naturally-infected papaya plants (var. Red Lady). Disease severity and fruit yield were quantified over a period of six months and defense-related enzyme activity in leaves was quantified with spectrophotometry. At the sixth month after transplanting, SS-treated plants with the mixture of Bacillus isolates and the combined mixture of Pseudomonas and Bacillus isolates showed a significantly lower \% disease index on foliage than the plants under control and the Pseudomonas mixture treatments. A significantly lower \% disease index was shown on the fruits treated with all the bacterial treatments applied by both methods, in comparison to the untreated control. Mixture of Pseudomonas isolates and the combined treatment with Pseudomonas and Bacillus isolates, when applied as the SS method, gave significantly higher fruit yield than that of the control treatment. Activities of peroxidase and phenylalanine ammonia lyase were significantly higher in plants treated with the mixture of Pseudomonas isolates by SS method while $\beta$-1,3-glucanase activity was significantly higher when applied the same treatment by SD method. Findings revealed the ability to reduce severity of PRSVD and induce defense-related enzymes when mixtures of Pseudomonas and Bacillus spp. were applied under field conditions.

*Corresponding author : devikadecosta@gmail.com 


\section{INTRODUCTION}

Papaya ringspot virus diseases (PRSVD) caused by papaya ringspot virus (PRSV) is a major disease in papaya cultivations around the globe. The disease is characterized by leaf mosaic and chlorosis, water soaked oily streaks on petioles and upper part of the trunk, distortion of young leaves leading to shoestring appearance and yield loss (Purcifull et al., 1984). Plants infected by PRSV result in qualitative yield reductions where sugar level of the fruits gets reduced by $50 \%$ or more (Purcifull et al., 1984). PRSV is a member of the genus Potyvirus and the family Potyviridae and transmitted by many species of aphids (mainly Myzus persicae and Aphis gossypii) in a non-persistent manner. Management of PRSV has been successful with transgenic papaya varieties, cross protection and tolerant varieties (Tripathi et al., 2008).

Other than the use of germplasm having genetically-controlled resistance, plant diseases can be managed through the induction of host plant resistance mediated by various biotic and abiotic agents (i.e. virulent or avirulent pathogens, nonpathogens, cell wall fragments, plant extracts and synthetic chemicals) (Walters et al., 2005). Induced resistance in plants is of two types, namely systemic acquired resistance (SAR) and induced systemic resistance (ISR). SAR develops locally or systemically in response to, for example, pathogen infection or treatment with certain chemicals (e.g., 2,6dichloroisonicotinic acid [INA]) which is effective against a wide range of pathogens and is mediated by a salicylic acid [SA]dependent process (Walters et al., 2005). In contrast, ISR develops as a result of colonization of plant roots by plant-growthpromoting rhizobacteria (PGPR) and is mediated by a jasmonate- or ethylenesensitive pathway (Pieterse et al., 1998).

Induced systemic resistance (ISR) by PGPR is effective against fungal, bacterial, viral, insect and nematode pests (Van Loon et al., 1998; Ramamoorthy et al., 2001) as an eco-friendly plant protection approach. Induced systemic resistance promoted through PGPR provides physical and mechanical strength to the cell walls of the plants and changes physiological and biochemical status of the host leading to the synthesis of defense chemicals against the incoming pathogen (Ramamoorthy et al., 2001). Seed treatment using Pseudomonas fluorescens strain 89B-27 and Serratia marcescens strain 90-166 have reduced incidence and delayed the symptom development of cucumber mosaic virus in cucumber and tomato (Raupach et al., 1996). Further, soil application of $P$. fluorescens strain P3 has induced host plant resistance against tobacco necrosis virus disease in tobacco (Maurhofer et al., 1998).

Induced systemic resistance by PGPR has been used effectively to manage a range of plant diseases under field conditions. Field application of $P$. putida strain 89B-27, $S$. marcescens strain 90-166 and Favomonas oryzihabitans strain INR-5 have reduced angular leaf spot and anthracnose of cucumber under field conditions along with growth promotion and enhancement of yield (Wei et al., 1995). Instead of using individual strains, use of mixtures of PGPR strains and the better performance of such strain mixtures on reduction of plant diseases and enhanced growth performances under field conditions have been reported (Raupach and Kloepper, 1998).

Ranasinghe et al. (2018) isolated 20Pseudomonas and four Bacillus isolates from rhizospheric soil of papaya plantations in Sri Lanka. Application of these strains individually as seed and soil drench treatments, in a pot experiment has reported plant growth promotion, increase of yield and reduction of symptom development of PRSVD in papaya foliage.

Considering the beneficial effects of the isolated Pseudomonas and Bacillus spp. on management of PRSVD, plant growth promotion and better yield performances, this study was conducted to evaluate the field efficacy of the bacterial strains when applied as mixtures on the reduction of PRSVD and growth and yield performances. Further, the influence of bacterial isolates on the activity of selected defense-related enzymes was quantified when the mixtures of bacterial isolates were applied. 


\section{MATERIALS AND METHODS}

\section{Determination of field efficacy of PGPR mixtures in managing PRSVD}

\section{Experimental site}

A field experiment was conducted at Grain Legume and Oil Crop Research and Development Center, Department of Agriculture (DOA), Angunakolapelessa (DL1b agro-ecological region of Sri Lanka). Experimental period was from November 2017 - July 2018. The location was selected as this region has been identified by the DOA as a potential area for commercial papaya cultivation.

\section{Establishment and management of papaya plants}

Papaya (variety Red Lady) was transplanted with $3 \times 3 \mathrm{~m}^{2}$ spacing when the seedlings were 45 days old. Each planting pit had the dimensions of $0.5 \times 0.5 \times 0.5 \mathrm{~m}^{3}$ and was filled with compost: top soil: cow dung mixture of 1:1:1 ratio. Fertilizer application (basal and top dressings and Borax and $\mathrm{ZnSO}_{4}$ ) was done according to DOA recommendations.

\section{Bacterial isolates}

Five Pseudomonas isolates (one P. putida and four Pseudomonas spp.) and four Bacillus isolates (B. cereus) isolated from rhizosphere of healthy papaya plants and identified by Ranasinghe et al. (2018) were used for field and planthouse experiments. Identity of the bacterial isolates was confirmed through molecular methods (i.e. PCR amplification of the rRNA region and subsequent DNA sequencing and homology search by BLAST, NCBI).

\section{Treatments and method of application of the treatments}

Treatments were applied by two application methods, namely seed soak (SS) and soil drench (SD). The four treatments used were; T1- Mixture of five Pseudomonas isolates, T2 Mixture of four Bacillus isolates, T3- Mixture of five Pseudomonas isolates and four Bacillus isolates and T4- control (no application of any bacterial isolate). In SS treatment, papaya seeds were soaked overnight in bacterial suspensions having a cell concentration of $1 \mathrm{x}$ $10^{8} \mathrm{cfu} / \mathrm{ml}$ of each isolate, before planting. In
SD method 45 days old papaya plants were applied as a soil drench (100 ml/ plant) with above bacterial treatments at the time of transplanting. Thereafter, the plants under SD treatment were applied with the freshlyprepared suspensions of the same bacterial isolates at one month intervals $(250 \mathrm{ml} /$ plant). Plants were allowed to get naturallyinfected with the PRSV. Each treatment was replicated three times in a randomized complete block design and each replicate contained 12 plants.

\section{Data collection and analysis}

Disease severity of the foliage was recorded at monthly intervals according to the following scale developed in the present study (Table 1).

Disease severity of the fruits was recorded according the following scale developed for the present study based on the \% of fruit surface area having ringspot symptoms. 0$0 \%$, 1- less than $25 \%$, 2- 26-50 \%, 3- 51-75 \% and 4- more than $76 \%$.

Fruit yield was collected for 10 picks. Disease severity of foliage and fruits was calculated by the following formula (McKinney, 1923).

Percentage Disease Index (PDI)

PDI $=\frac{\text { Sum of all numerical ratings } \times 100}{\text { Total number of observations } \times \text { Maximum rating }}$

Treatment variation was determined by ANOVA and the mean separation was done by Duncan's multiple range test using SAS 9.1 software.

\section{Confirmation of PRSV infection by RT-PCR}

As plants were allowed to be infected by PSRV naturally, infection was confirmed by RT-PCR using PRSV coat protein specific primers, MB 11 and MB 12 (Temaja et al., 2015). RNA was extracted from immature young leaves of plants at the flowering stage by silica RNA extraction protocol (Gunasinghe et al., 2009). Extracted total RNA was used for cDNA synthesis using Maxima reverse transcriptase according to manufacturer's protocol (Thermo Fisher Scientific, USA). cDNA mixture was used to amplify with MB 11 and MB 12 primers and a PCR product of $905 \mathrm{bp}$ was expected (Temaja et al., 2015). PCR products were DNA sequenced and subjected to DNA homology search (BLAST, NCBI). 
Table 1: Details of the symptoms used to develop the scale for disease severity of foliage

\begin{tabular}{|c|c|}
\hline Scale & Description of the severity of symptoms \\
\hline 0 & No symptoms \\
\hline 1 & Less than $25 \%$ of the canopy having mild symptoms and $0 \%$ moderate symptoms \\
\hline 2 & $26-50 \%$ of the canopy having mild symptoms and $0 \%$ moderate symptoms \\
\hline 3 & $\begin{array}{l}51-75 \% \text { of the canopy having mild symptoms and less than } 25 \% \text { of the canopy having } \\
\text { moderate symptoms }\end{array}$ \\
\hline 4 & $\begin{array}{l}\text { more than } 75 \% \text { of the canopy having mild symptoms and } 26-50 \% \text { of the canopy } \\
\text { having moderate symptoms }\end{array}$ \\
\hline 5 & $\begin{array}{l}\text { Less than } 25 \% \text { of the canopy having severe symptoms and } 51-75 \% \text { of the canopy } \\
\text { having moderate symptoms }\end{array}$ \\
\hline 6 & $26-50 \%$ of the canopy having severe symptoms \\
\hline 7 & more than $76 \%$ of the canopy having moderate symptoms \\
\hline 8 & $51-75 \%$ of the canopy having severe symptoms \\
\hline 9 & $100 \%$ of the canopy has severe symptoms \\
\hline
\end{tabular}

Note: Mild, moderate and severe symptom categories on leaves were defined as follows: mild symptoms $-<25 \%$ of the leaf area showing mosaic symptoms and reduction of leaf lamina in one lobe, moderate symptoms - $26-50 \%$ of the leaf area showing mosaic symptoms and reduction of leaf lamina in 2-3 lobes and severe symptoms - $51 \%$ of the leaf area showing mosaic symptoms and reduction of leaf lamina in more than three lobes with shoe string appearance

\section{Determination of the defense enzyme activity due to bacterial treatments}

\section{Experimental site and treatment structure}

An open field pot experiment was established at Plant Virus Indexing Center, Homagama. Papaya (variety Red Lady) seeds and plants were treated with six different treatments by SS and SD methods as described in the field experiment elsewhere in the text. The treatment details are given in Table 2 .

Each treatment was replicated three times and maintained in a completely randomized design. Mechanical inoculation of PRSV was done for plants under T1, T3 and T5 treatments at the age of 45 days after seeding.

\section{Quantification of defense enzymes}

Leaf samples were collected from plants treated with treatments (T1-T6), before inoculation of PRSV and 1, 24, 48, 72, 96, 120 and 144 hours after inoculation of PRSV. These leaf samples were subjected to quantification of peroxidase (POX), phenylalanine ammonia lyase (PAL) and $\beta-1,3-$ glucanase activity by methods described by Hammerschmidt et al. (1982), Dickerson et al. (1984) and Pan et al. (1991), respectively. Treatment variation on defense enzymes was determined by ANOVA and the mean separation was done by Duncan's multiple range test using SAS 9.1 software.

Table 2. Details of the treatments used to determine the activity of defense enzymes

\begin{tabular}{ll}
\hline Treatment & \multicolumn{1}{c}{ Description of the treatment } \\
\hline T1 & Positive control (not treated with any bacterial suspension and inoculated with PRSV) \\
T2 & Negative control (not treated with any bacterial suspension and not inoculated with PRSV) \\
T3 & Mixture of five Pseudomonas isolates treated by SS and inoculated with PRSV \\
T4 & Mixture of five Pseudomonas isolates treated by SS and not inoculated with PRSV \\
T5 & Mixture of five Pseudomonas isolates treated by SD and inoculated with PRSV \\
T6 & Mixture of five Pseudomonas isolates treated by SD and not inoculated with PRSV \\
\hline
\end{tabular}




\section{RESULTS AND DISCUSSION}

\section{Field efficiency of bacterial mixtures on management of PRSV}

\section{Disease severity of plant canopy}

Plants treated with the bacterial mixtures showed no significant difference between the methods of applications of the bacterial mixtures with reference to the disease severity (percentage disease index PDI) of plant canopy. PDIs of leaves exhibited by SS and SD-treated plants using four different bacterial treatments, over a period of six months are shown in Figures $1 \mathrm{a}$ and $1 \mathrm{~b}$, respectively.
At the sixth month after transplanting, SStreated plants with the mixture of Bacillus isolates and the combined mixture of Pseudomonas and Bacillus isolates showed a significantly lower \% disease index than the control and the Pseudomonas mixture treatments (Figure 1a). The plants treated with SD treatment by the combined mixture of Pseudomonas and Bacillus isolates gave a lower \% DI values than all the other treatments throughout the experimental period (Figure $1 b$ ).

(a)

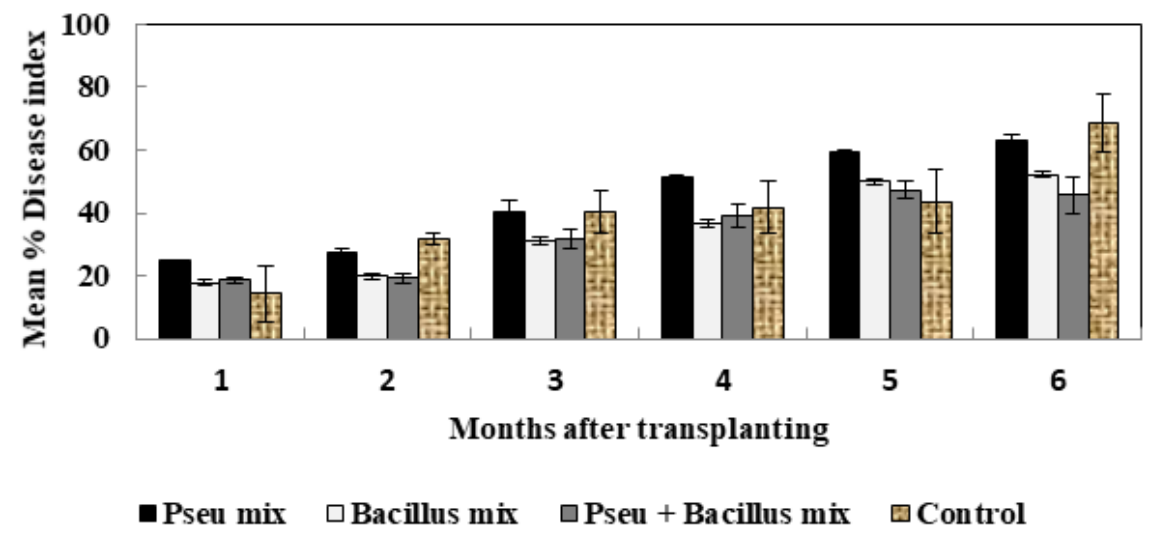

(b)

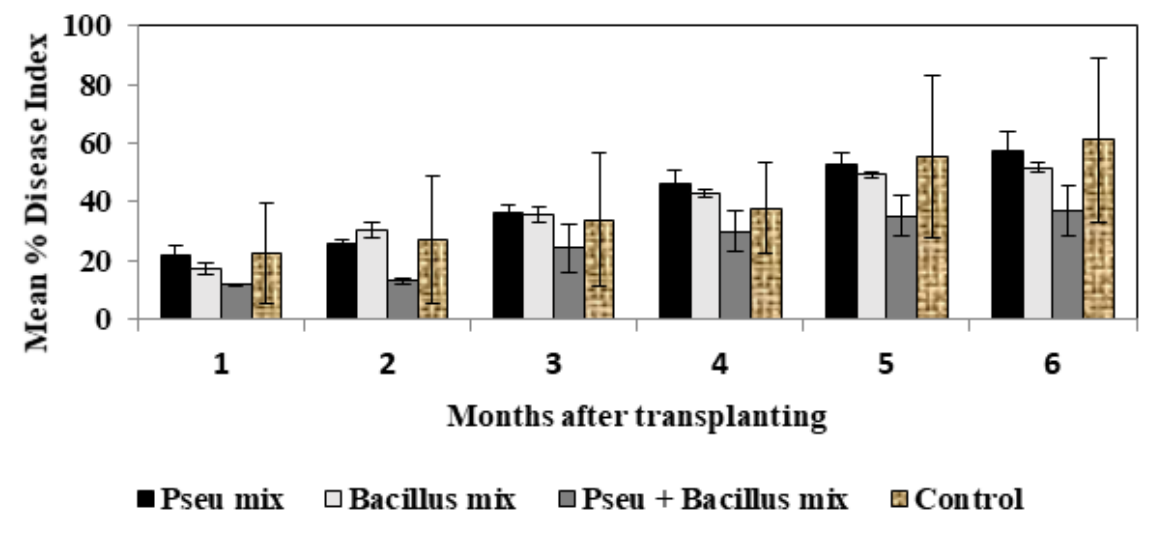

Figure 1: Disease severity of leaf symptoms (Mean \% disease index) under field conditions when bacterial isolates were applied as mixtures by SS method (a) and SD method (b). Error bars indicate standard errors of means.

In vivo efficiency of controlling plant virus diseases by several plant growth promoting rhizobacteria (PGPR) has been well documented. Control of Tobacco necrosis virus in tobacco by Pseudomonas fluorescens strain CHAO (Maurhofer et al., 1998), Tobacco mosaic virus in tobacco by $P$. aeruginosa strain 7NSK2 (De Meyer et al. 1999), Tomato mottle virus and Cucumber mosaic virus in tomato by Bacillus subtilis 
IN937b and $B$. pumilus strain SE34, respectively (Murphy et al. 2000; Murphy et al. 2003) are few examples.

Similar findings on reduction of disease severity of PRSVD have been observed when four Pseudomonas spp., P. fluorescens and a Bacillus sp. were applied as individual isolates through seed treatment and soil drench methods under field conditions in the Wet zone of Sri Lanka (WL3 agroecological zone) (Ranasinghe et al., 2018). Effectiveness of biological control using microorganism such as rhizobacteria depends on crucial factors such as environment condition and soil type (Damayanthi et al., 2007). However, results of present study and findings of Ranasinghe et al. (2018), confirmed the field performance of the indigenous Pseudomonas and Bacillus isolates as promising candidates in managing PRSVD, either as individual isolates or mixtures under different agroecological regions with contrasting environmental and climatic conditions. Because DL1b region which is located in the Dry zone of Sri Lanka, has been identified as an agroecological region which is slightly wet during Maha season (September to February) and a severe drought severity having agroecological region during the Yala (March to August) season (Chitranayana and Punyawardena, 2008).

\section{Fruit Yield}

Table 3. Average yield of $\mathbf{1 0}$ picks given by the plants under four different treatments at field conditions.

\begin{tabular}{lcc}
\hline Treatment & $\begin{array}{c}\text { Seed Soak } \\
\text { method }\end{array}$ & $\begin{array}{c}\text { Soil Drench } \\
\text { method }\end{array}$ \\
\hline Pseu mix & $11.99^{\mathrm{a}}$ & $8.27^{\mathrm{a}}$ \\
Bacillus mix & $8.21^{\mathrm{ab}}$ & $6.91^{\mathrm{a}}$ \\
Pse +Bacillus & $10.18^{\mathrm{a}}$ & $10.44^{\mathrm{a}}$ \\
mix & & \\
Control & $4.90^{\mathrm{b}}$ & $4.62^{\mathrm{a}}$ \\
CV $(\%)$ & 27.39 & 25.62 \\
\hline
\end{tabular}

Values with the same letter along a column are not significantly different at $(\mathrm{P}=0.05)$

Mixture of Pseudomonas isolates and the combined treatment with Pseudomonas and Bacillus isolates when applied as the SS method gave significantly higher fruit yield than that by the control treatment (Table 3). However, mixture of Bacillus isolates when applied by SS method did not give a significantly higher fruit yield than that in control plants. Fruit yield was not significantly different among the treatments when they were applied by SD method (Table 3). Better yield performances of papaya under field conditions have been reported by Ranasinghe et al. (2018) when $P$. fluorescens, Pseudomonas spp. and a Bacillus sp. were applied as single isolates by seed treatment method.

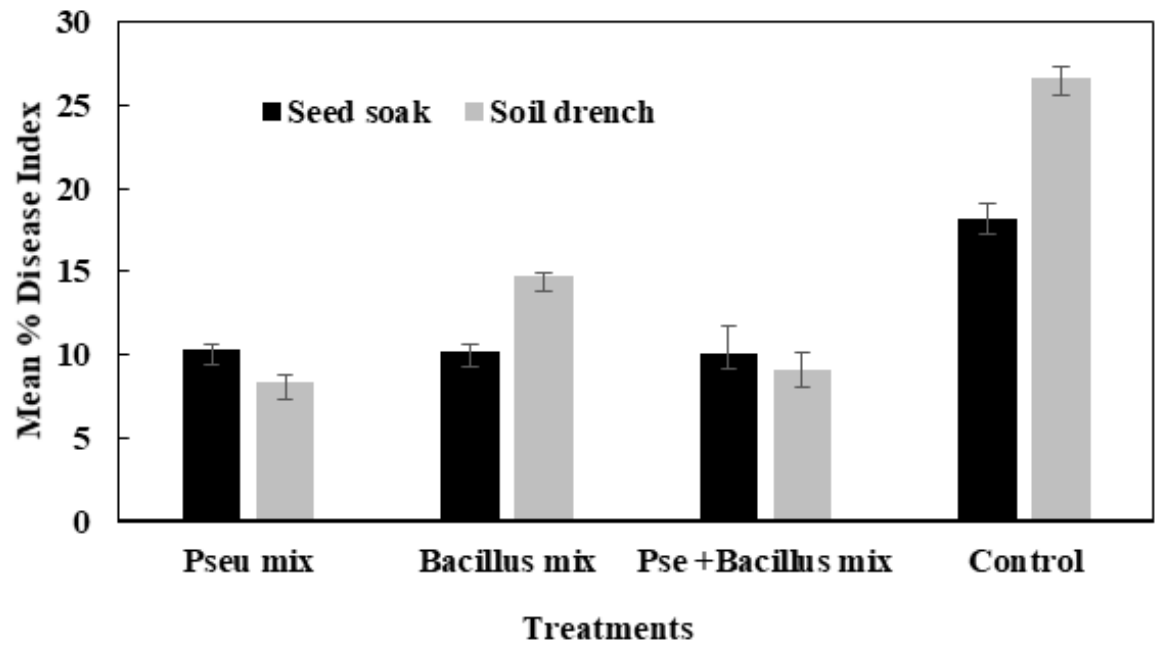

Figure 2: Percentage disease index of fruits due to different treatments of bacterial mixtures by seed soak and soil drench methods. Error bars indicate standard errors of means. 


\section{Disease severity of the fruits}

Significantly lower percentage disease index was shown on the fruits treated with all the bacterial treatments applied by both methods in comparison to the untreated control (Figure 2 ). It is worth noting the absence of typical ring spot symptoms on fruits in some plants, even though PRSV symptoms were present on their foliage.

\section{Molecular confirmation of the natural PRSV infection}

Seventy-five \% of the control-treated plants gave the expected PCR band size of $905 \mathrm{bp}$ when amplified with MB11 and MB12 primers. Results in PCR products were subjected to DNA sequencing and subsequent homology search confirmed the presence of PRSV by giving the highest match with papaya ringspot isolate of Sri Lanka coat protein mRNA (U14741.1) with a $93 \%$ query cover, an E value of 0.00 and a \% identity of 93.08 .

\section{Peroxidase activity}

Peroxidase (POX) activity in leaf tissues was signficantly higher in the plants treated with the mixture of Pseudomonas isolates by SS method than that of the other treatments (Figure 3). Among the SS-treated plants, artificially-inoculated PRSV ones had the highest peroxidase activity and the enzyme level elevated significantly from $48 \mathrm{hr}$ after the treatment. In contrast, the plants which were not artificially-inoculated with the virus but treated with the bacterial mixture by SS method, enhanced the peroxidase activity to a significantly higher level, starting from $72 \mathrm{hrs}$ after treatment (Figure 3). By the $144 \mathrm{hr}$ after treatment, SS treated plants which were inoculated with the pathogen and the plants under SS treatment but not inoculated with the pathogen showed 82 and $64 \%$ increase of the peroxidase activity, respectively, in comparison to the rest of the treatments. Damayanthi et al., (2007) have observed higher peroxidase activity in pepper plants which were challenge-inocuated with tobacco mosaci virus than the plants which were not inoculated. Eventhough a significant increase of the peroxidase activity was shown by the SD method at $72 \mathrm{hr}$ after treatment in both inoculated and non-inoculated plants (Figure 3), SD method has not shown a successful increase of peroxidase activity thereafter.

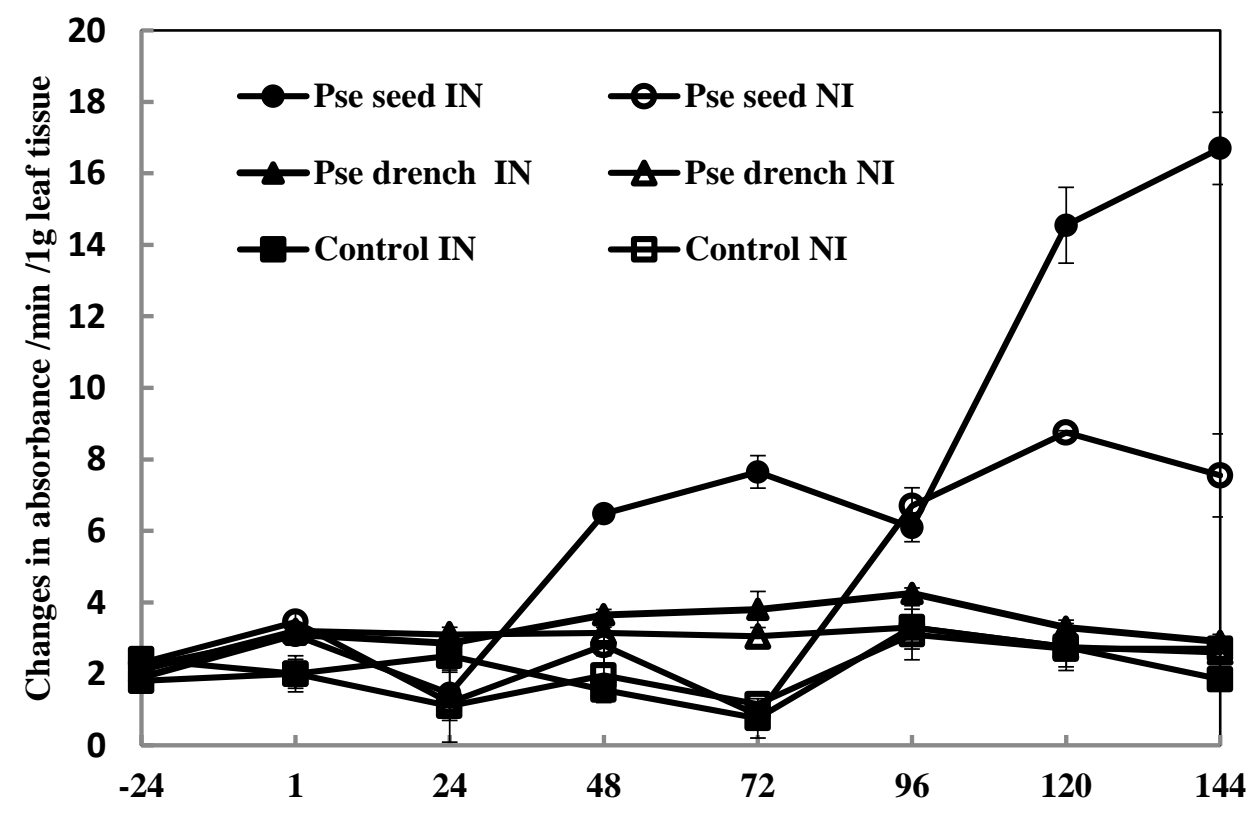

Time of sample collection - hrs from PRSV inoculation

Figure 3: Changes in peroxidase activity in leaf tissues of papaya subjected to a mixture of Pseudomonas spp. by SS and SD methods, under challenged and non-challenged conditions by the viral pathogen. Error bars indicate standard errors of means. 
POX is a distinguished class of Pathogenesis related (PR) protein and induced in host plant tissues by pathogen infection and reported to be a key enzyme involved in lignification, cross linking of cell wall polysaccharides, oxidation of indole-3-acetic acid, cell elongation regulation, healing of wounds, oxidation of phenolic compounds, and plant defense (Thakker et al., 2013). When POX level increases due to the induced systemic resistance, quick synthesis of reactive oxygen derivatives by oxidative burst leads to cell death and inhibition of pathogenic activities (Halfeld-Vieira et al., 2006). On par with the findings of the present study, application of $P$. aeruginosa increased the POX activity about 4.89 to 6.49 times when compared to untreated control plants against soya bean stunt virus in soyabean (Khalimi and Suprapta, 2011).

\section{$\beta-1,3-$ glucanase activity}

$\beta$-1,3-glucanase activity has increased significantly in plants inoculated with PRSV and treated with the mixture of Pseudomonas as a soil drench. In this treatment, enzyme activity has increased significantly compared to all the other treatments, though a reduction of the enzyme activity was observed at $24 \mathrm{hr}$ after the treatment (Figure 4). A significant increase of the enzyme activity was reported in the plants inoculated and non-inoculated with the virus and treated the bacterial mixture as a seed treatment at $144 \mathrm{hr}$ after the treatment (Figure 4). $\beta$-1,3-glucanase is a member of the pathogenesis-related protein (PR) family, known to directly destroy pathogen cell walls; its degradation products are oligosaccharides that may subsequently induce disease resistance-related enzymes such as Phenylalanine ammonia lyase (PAL) (Keen and Yoshikawa, 1983). On par with the findings of the present study, Edreva (2005) reported the highest $\beta$-1,3-glucanase and viral inhibitory activity in plants treated with Pseudomonas fluorescens. High $\beta-1,3-$ glucanase and peroxidase activities in the leaves treated with P. fluorescens and Bacillus globisporus culture filtrates reduced the incidence of tobacco necrotic virus in bean plants (Shoman et al., 2003).

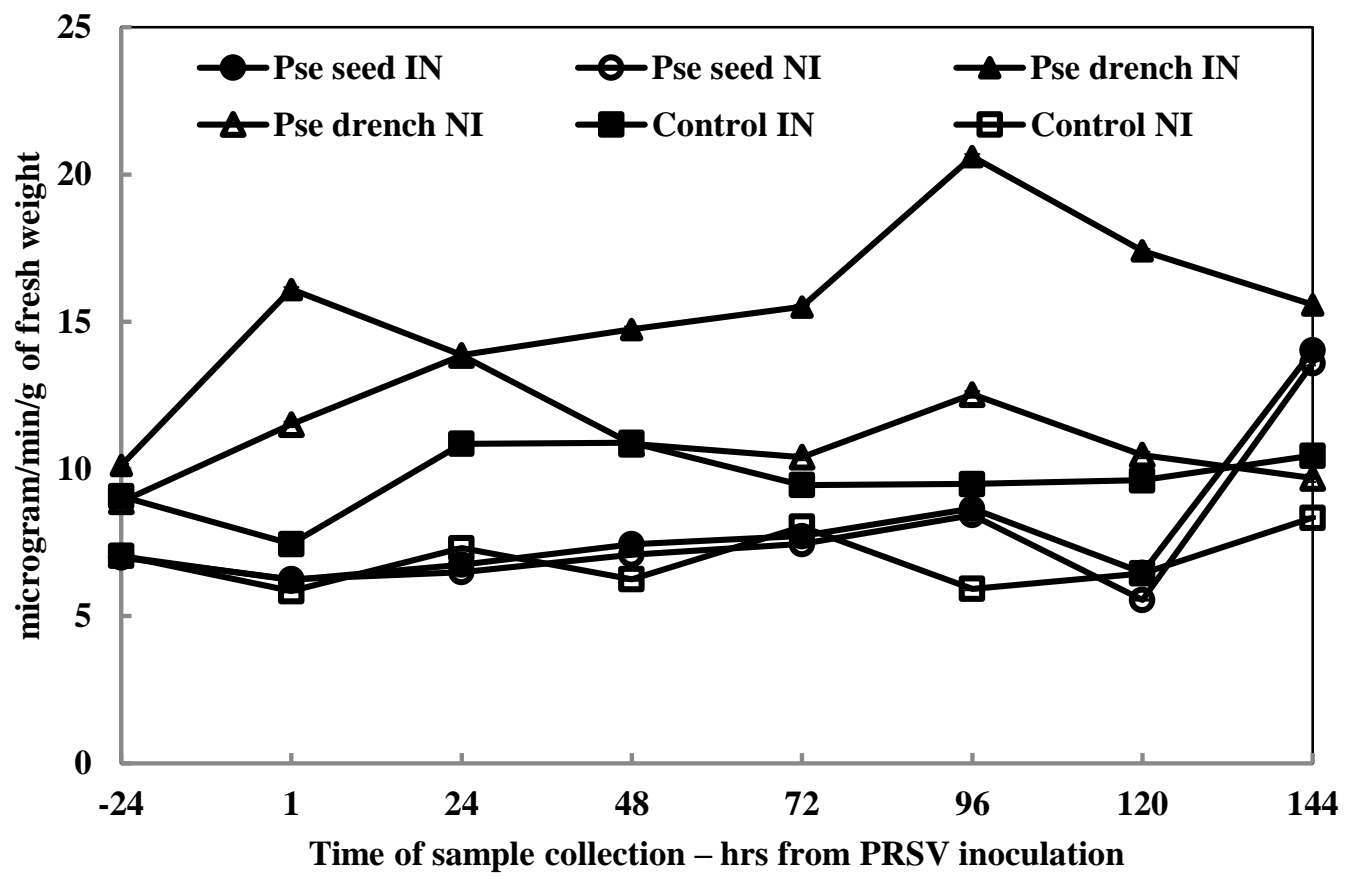

Figure 4: Changes in $\beta$-1,3-glucanase activity in leaf tissues of papaya subjected to a mixture of Pseudomonas spp. by SS and SD methods, under challenged and un-challenged conditions by the viral pathogen. Error bars indicate standard errors of means. 


\section{PAL activity}

The highest PAL activity was reported in plants treated with Pseudomonas mixture as a seed treatment and inoculated with the virus, from $120 \mathrm{hr}$ after the treatment (Figure 5) and it was significantly higher than the plants under the same treatment but non- challenged with the viral pathogen. The levels of PAL activity in leaves of the plants treated with seed treatment was higher than that of the plants under soil drench treatment (Figure 5). The enzyme PAL initiates the phenylpropanoid pathway, resulting in the biosynthesis of phytoalexins and/or phenolic compounds. Application of PGPR to plants have suppressed the early blight disease in tomato and rice blast pathogen by elevating the activity of PAL, PO, PPO, chitinase, $\beta 1,3$-glucanase, superoxide dismutase, catalase, lipoxygenase, and phenolics in plant tissues treated with PGPR (Senthilraja et al., 2013; Raise et al., 2017).
The results revealed that peroxidase and PAL activity was higher when the plants were treated by the SS method, but $\beta$-1,3glucanase activity was higher in plant leaves when treated with the bacteria by SD method, indicating an effect of the method of application of bacterial consortia on enhancement activity of different enzymes. Variation in the disease reduction effects of PGPR have been reported in field trails at multiple locations and due to abiotic factors, such as soil fertility, temperature and moisture (Hol et al., 2013). Therefore, method of application of PGPR could have an indirect effect by the above ecological parameters.

In conformity with the present study, Srinivasan and Mathivanan (2011) have reported the efficiency of using consortia of PGPR (i.e. B. licheniformis, Bacillus spp., $P$. aeruginosa and Streptomyces fradiae) to reduce the sunflower necrosis virus disease under field conditions when applied as seed and soil treatments.

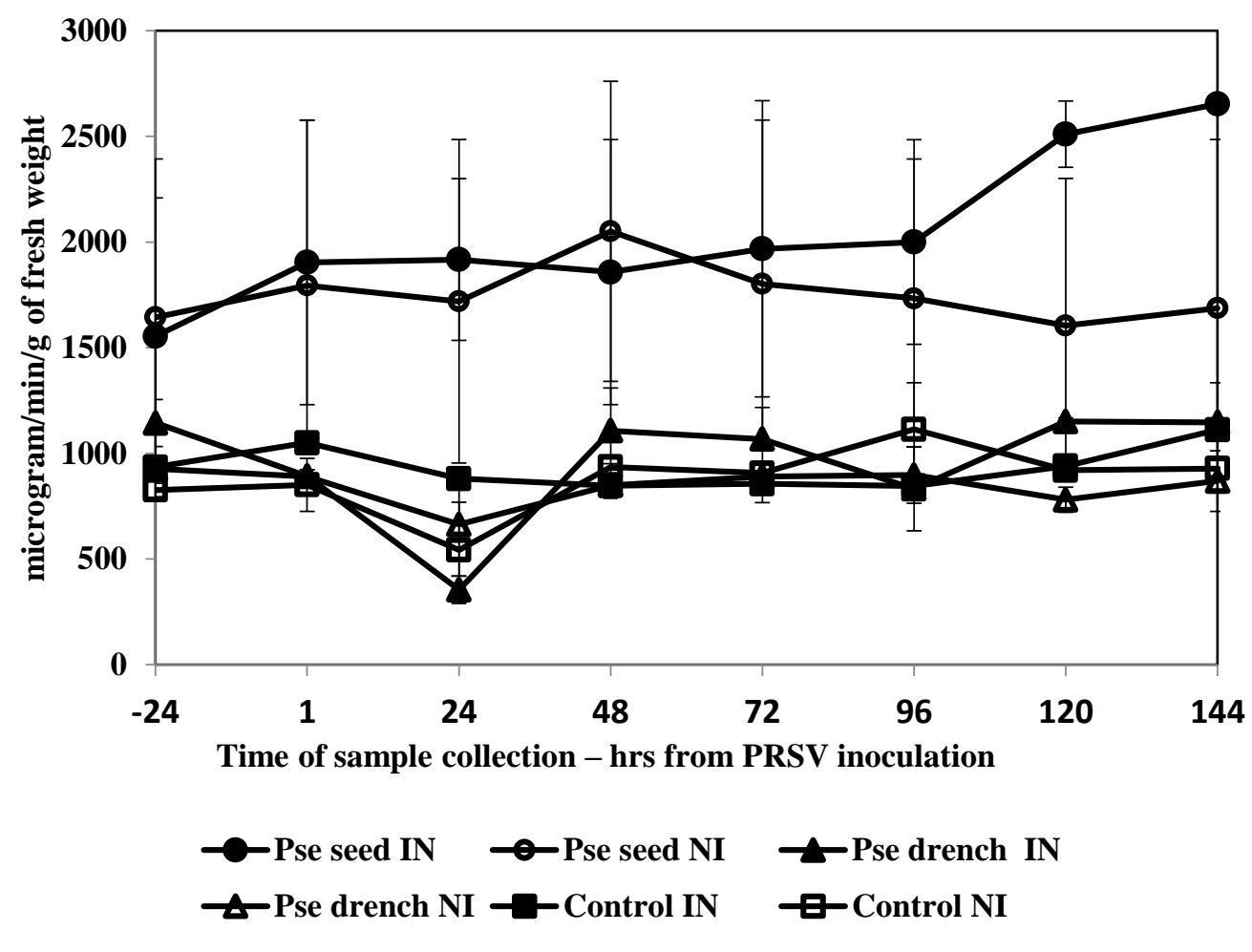

Figure 5: Changes in PAL activity in leaf tissues of papaya subjected to a mixture of Pseudomonas spp. by SS and SD methods, under challenged and non-challenged conditions by the viral pathogen. Error bars indicate standard errors of means. 


\section{CONCLUSIONS}

Application of mixture of $B$. cereus, Pseudomonas spp., and P. putida by seed soak and soil drench methods reduced the percentage disease index of PRSVD under field conditions in DL1b agroecological zone of Sri Lanka. Soaking papaya seeds by a mixture of Pseudomonas spp. increased peroxidase and PAL activity in leaf tissues while drenching the soil with the same bacterial mixture enhanced the $\beta-1,3$-glucanase activity in leaves.

\section{ACKNOWLEDGEMENT}

Authors wish to acknowledge staff of the Plant Pathology Division at Grain Legume and Oil Crop Research and Development Center, Angunakolapellassa for support given to carry out field trial and staff of the Molecular Division at Plant Virus Indexing Center, Homagama for molecular work.

\section{REFERENCES}

Chithranayana, R.D. and Punyawardena, B.V.R. (2008). Identification of drought prone agro-ecological regions in Sri Lanka. Journal of National Science Foundation of Sri Lanka. 36(2), 117-123.

Damayanthi, T.A., Pardede,H. and Mubarik, N.R. (2007). Utilization of root colonizing bacteria to protect hot pepper against Tobacco mosaic tobamovirus. HAYATI Journal of Biosciences. 105-109.

De Meyer, G., Audenaert, K. and Höfte, M. (1999). Pseudomonas aeruginosa 7NSK2induced systemic resistance in tobacco depends on in planta salicylic acid accumulation but is not associated with PR1a expression. European Journal of Plant Pathology. 105(5), 513-517.

Dickerson, D.P., Pascholati, S.F., Hagerman, A.E., Butler, L.G. and Nicholson, R.L. (1984). Phenylalanine ammonia-lyase and hydroxycinnamate: CoA ligase in maize mesocotyls inoculated with Helminthosporium maydis or Helminthosporium carbonum. Physiological Plant Pathology. 25(2), 111-123.

Edreva, A. (2005). Pathogenesis-related proteins: research progress in the last 15 years. General and Applied Plant Physiology. 31(1-2), 105-24.

Gunasinghe, W.A.D.S.K., Dassanayake, E.M. and Ubeysekara, N.M (2009). Successful detection of RNA viruses by reverse transcription polymerase chain reaction. Annals of Sri Lanka, Department of Agriculture. 11, 57-62.

Halfeld-Vieira, B.D.A., Vieira Júnior, J.R., Romeiro, R.D.S., Silva, H.S.A. and BaracatPereira, M.C. (2006). Induction of systemic resistance in tomato by the autochthonous phylloplane resident Bacillus cereus. Pesquisa Agropecuária Brasileira. 41(8), 1247-1252.

Hammerschmidt, R., Nuckles, E.M. and Kuć, J. (1982). Association of enhanced peroxidase activity with induced systemic resistance of cucumber to Colletotrichum lagenarium. Physiological Plant Pathology. 20(1), 73-82

Hol, W.H., Bezemer, T.M. and Biere, A. (2013). Getting the ecology into interactions between plants and the plant growthpromoting bacterium Pseudomonas fluorescens. Frontiers in Plant Science. 4, 81.

Keen, N.T. and Yoshikawa, M. (1983). $\beta-1,3-$ Endoglucanase from soybean releases elicitor-active carbohydrates from fungus cell walls. Plant Physiology, 1(3), 460-465.

Khalimi, K. and Suprapta, D.N. ( 2011). Induction of plant resistance against Soybean stunt virus using some formulations of Pseudomonas aeruginosa. Journal of the International Society for Southeast Asian Agricultural Sciences. 17(1), 98-105.

Maurhofer, M., Reimmann, C., SchmidliSacherer, P., Heeb, S., Haas, D. and Défago, G. (1998). Salicylic acid biosynthetic genes expressed in Pseudomonas fluorescence strain P3 improve the induction of systemic resistance in tobacco against tobacco necrosis virus. Phytopathology. 88(7), 678684.

McKinney, H.H. (1923). A new system of grading plant diseases. Journal of Agricultural Research. 26(2), 195-218.

Murphy, J.F., Zehnder, G.W., Schuster, D.J., Sikora, E.J., Polston, J.E. and Kloepper, J.W. (2000). Plant growth-promoting 
rhizobacterial mediated protection in tomato against Tomato mottle virus. Plant Disease. 84(7), 779-784.

Murphy, J.F., Reddy, M.S., Ryu, C.M., Kloepper, J.W. and Li, R. (2003). Rhizobacteriamediated growth promotion of tomato leads to protection against Cucumber mosaic virus. Phytopathology. 93(10), 1301-1307.

Pan, S.Q., Ye, X.S. and Kuć, J. (1991). Associations of $\beta$-1, 3-glucanase activity and isoform pattern with systemic resistance to blue mould in tobacco induced by stem injection with Peronospora tabacina or leaf inoculation with tobacco mosaic virus. Physiological and Molecular Plant Pathology. 39(1), 25-39.

Pieterse, C. M. J., Van Wees, S. C. M., Van Pelt, J. A., Knoester, M., Laan, R., Gerrits, H., Weisbeck, P. J., and Van Loon, L. C. (1998). A novel signaling pathway controlling induced systemic resistance in Arabidopsis. Plant Cell. 10:1571-1580.

Purcifull D, Edwardson J, Hiebert E, Gonsalves D. 1984. Papaya ringspot virus. CMI/AAB Descr. Plant Viruses, No. 292. (No. 84 Revis., July 1984). 8.

Rais, A., Jabeen, Z., Shair, F., Hafeez, F.Y. and Hassan, M.N. (2017). Bacillus spp., a biocontrol agent enhances the activity of antioxidant defense enzymes in rice against Pyricularia oryzae. PLoS ONE. 12(11). e0187412. https://doi.org/10.1371/ journal.pone.0187412.

Ramamoorthy, V., Viswanathan, R., Raguchander, T., Prakasam, V. and Samiyappan, R. (2001). Induction of systemic resistance by plant growth promoting rhizobacteria in crop plants against pests and diseases. Crop Protection. $20(1), 1-11$.

Ranasinghe, C., De Costa, D.M., Basnayake, B.M.V.S., Gunasekera, D.M., Priyadharshani, S. and Navagamuwa, N.V.R. (2018). Potential of rhizobacterial Pseudomonas and Bacillus spp. to manage papaya ringspot virus disease of papaya (Carica papaya (L.). Tropical Agricultural Research. 29(4), 271-283.

Raupach, G. S., and Kloepper, J. W. (1998). Mixtures of plant growth promoting rhizobacteria enhance biological control of multiple cucumber pathogens. Phytopathology. 88:1158-1164.

Raupach, G.S., Liu, L., Murphy, J.F., Tuzun, S. and Kloepper, J.W. (1996). Induced systemic resistance in cucumber and tomato against cucumber mosaic cucumovirus using plant growth-promoting rhizobacteria (PGPR). Plant Diseases, 80(8), 891-894.

Senthilraja, G., Anand, T., Kennedy, J., Raguchander, T., Samiyappan, R. (2013). Plant growth promoting rhizobacteria (PGPR) and entomopathogenic fungus bioformulation enhance the expression of defense enzymes and pathogenesis-related proteins in groundnut plants against leaf miner insect and collar rot pathogen. Physiological and Molecular Plant Pathology. 82:10-9.

Shoman, S.A., Abd-Allah, N.A. and El-Baz, A.F. (2003). Induction of resistance to tobacco necrosis virus in bean plants by certain microbial isolates. Egyptian Journal of Biology. 5(1), 10-18.

Srinivasan, K. and Mathivanan, N. (2011). Plant growth promoting microbial consortia mediated classical bio control of sunflower necrosis virus disease. Journal of Biopesticides. 4(1), 65.

Temaja, I.G.R.M. and Darmiati, I.P.S.N.N. (2015). Papaya ringspot virus (PRSV) causing ringspot disease on papaya in Bali. Journal of Biology, Agriculture and Healthcare. 5(18), 50-55.

Thakker, J.N, Patel, S., Dhandhukia, P.C. (2013) Induction of defense-related enzymes in banana plants: effect of live and dead pathogenic strain of Fusarium oxysporum f. sp. cubense. ISRN Biotechnology. doi: 10.5402/2013/601303

Tripathi, S., Suzuki, J.Y., Ferreira, S.A. and Gonsalves, D.(2008). Papaya ringspot virus$P$ : characteristics, pathogenicity, sequence variability and control. Molecular Plant Pathology. 9(3), 269-280.

Van Loon, L.C., Bakker, P.A.H.M. and Pieterse, C.M.J. (1998). Systemic resistance induced by rhizosphere bacteria. Annual Review of Phytopathology. 36(1), 453-483. 
Walters, D. R., Newton, A. C. and Lyon, G. D. (2005). Induced resistance: Helping plants to help themselves. Biologist. 52:28-33.

Wei, G., Yao, G.W ehnder, S., Tuzun, S. and Kloepper, J.W. (1995). Induced systemic resistance by selected plant growth promoting rhizobacteria against bacterial wilt of cucumber and the beetle vectors. Phytopathology. 85, 1154. 